\title{
JETTIES AT BODEGA HARBOR
}

\author{
Orville T. Magoon ${ }^{1}$, Donald D. Treadwell ${ }^{2}$, and Paul S. Atwood ${ }^{3}$
}

\begin{abstract}
To create and maintain a navigable entrance for small craft between the Pacific Ocean and the natural lagoon now referred to as Bodega Harbor, the construction of two rubble-mound jetties and the associated dredging of interior channels were authorized by the United States Congress in the late 1930s. The jetties were built by the United States Army Corps of Engineers in the early 1940s. Elements of the planning, design, construction, monitoring, and maintenance of the jetties are discussed herein.
\end{abstract}

Keywords: rubble-mound jetties; long-term performance; monitoring; maintenance; Bodega Bay; Bodega Harbor

\section{INTRODUCTION}

Bodega Harbor, a lagoon connected to Bodega Bay and the Pacific Ocean, is located on the California coast of the United States about 50 miles north of San Francisco. The Pacific Ocean areas offshore of Bodega Bay are excellent for both commercial and recreational fishing. However, the natural unimproved entrance to Bodega Harbor, both shallow and unstable, was very difficult to navigate safely.

The project undertaken in the early 1940s by the United States government to improve the situation included two entrance channel jetties, a bulkhead to help retain the natural sandspit, and dredging of interior channels and turning basins. Figure 1 is an aerial view of the jetties, the sandspit, a portion of the dredged channels, and the seaward (western) end of the peninsula known as Bodega Head.

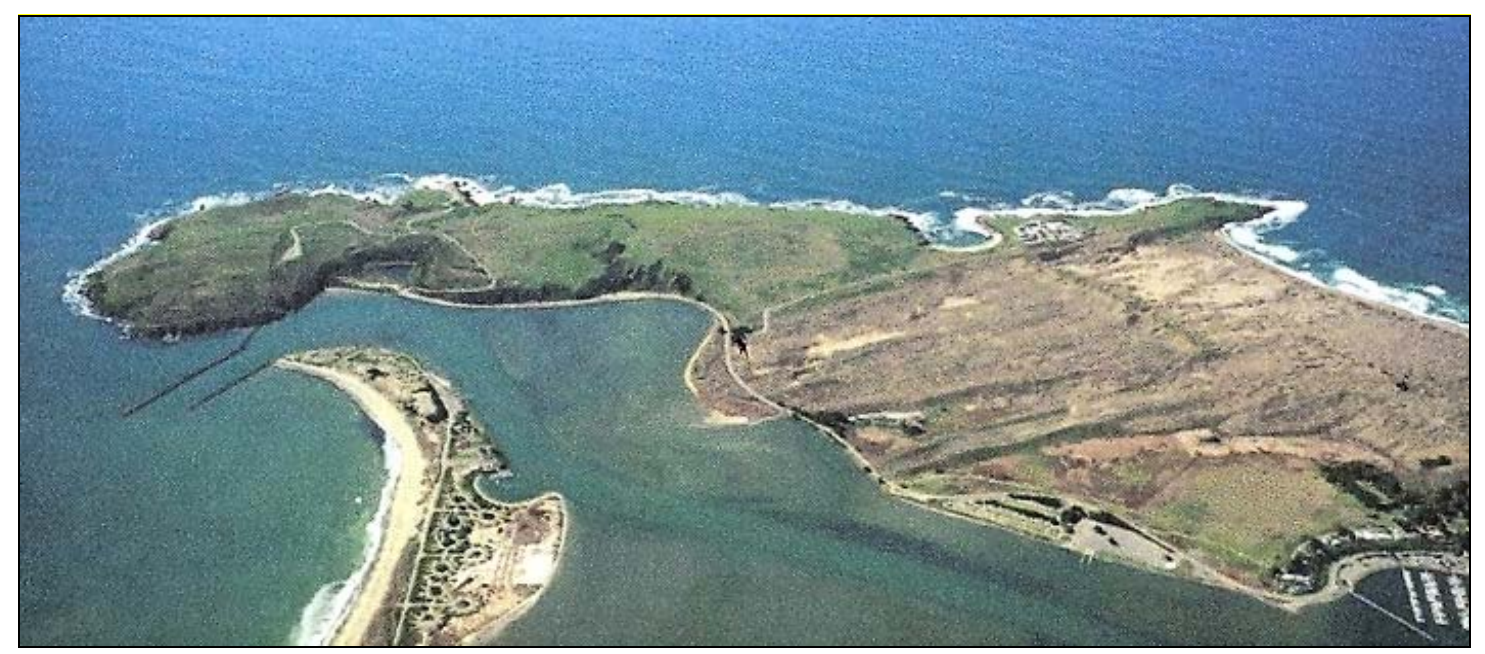

Figure 1. Aerial View of Jetties and Dredged Entrance Channel at Bodega Harbor

\section{PHYSICAL AND GEOLOGIC SETTING}

The climate at Bodega Harbor in western Sonoma County is temperate and there is little variation between summer and winter temperatures with few days falling below freezing. On the south, Bodega Harbor is separated from Bodega Bay and the Pacific Ocean by the long hooked sandspit (known as Doran Beach) that extends westward from the mainland to the tidal inlet.

The Bodega Bay area is of considerable geologic significance as the trend of the Sonoma coastline is in large measure controlled by the San Andreas Fault Zone. For thousands of years, Bodega Harbor remained essentially undisturbed, a submerged portion of the fault zone. Until about the mid-1800s, it appears that the natural rate of sedimentation had been balanced over the millennia by natural erosion processes and by earthquakes that loosened sediment and perhaps dropped the floor of the harbor.

\footnotetext{
${ }^{1}$ Consulting Engineer, San Francisco, California, USA; omagoon@sbcglobal.net

${ }^{2}$ Consulting Engineer, Sausalito, California, USA; ddtreadwell@comcast.net

${ }^{3}$ Water Resources Center Archives, University of California, Berkeley, California, USA; patwood@library.berkeley.edu
} 
The San Andreas Fault is part of the "Pacific Ring of Fire", an arc of intense earthquake and volcanic activity that stretches from New Zealand along the eastern edge of Asia, north and east across the Aleutian Islands of Alaska, and south along the coasts of North and South America. The crust of the Earth is fractured into a series of "plates" that have been moving very slowly over the Earth's surface for millions of years.

Two of these moving plates meet along the Pacific Coast of California in the United States; the boundary between them is the San Andreas Fault. The Pacific Plate (on the west) moves northwestward relative to the North American Plate (on the east), causing earthquakes along the fault. The San Andreas Fault system is more than 800 miles long and extends to depths of at least 10 miles within the Earth. In detail, the fault is a complex zone of crushed and broken rock ranging from about 300 to 5,000 feet wide (Schulz and Wallace, 1997).

In the general area of San Francisco, many investigators (e.g., USGS, 2001) have mapped the trace of the San Andreas Fault. The fault passes northwestward along the San Francisco peninsula, then out to sea at Mussel Rock across the Gulf of the Farallones (Treadwell et al, 1980), making landfall in Marin County at the inlet to Bolinas Lagoon. It then continues in a northerly direction through the Olema Valley and Tomales Bay before going out to sea again north of Bodega Head on the coastline of Sonoma County (Iacopi, 1964; Treadwell, Noble, and Magoon, 2005).

Bodega Bay represents a northerly continuation of the Tomales Bay depression (Figure 2). Both Tomales Bay and Bodega Harbor are oriented along the alignment and contained within the limits of the fault zone, as is Bolinas Lagoon farther to the south. Bodega Harbor occupies a portion of the fault zone, with contrasting rocks of the opposite sides of the zone being exposed on Bodega Head and on the mainland (Koenig, 1975). Geologic maps show the peninsular connection of Bodega Head to the mainland on the east as covered by an area of sand dunes covering the shattered rocks of the fault zone.

Bodega Head is the seaward promontory of a peninsula slightly over two miles long and one-half mile wide (Figure 3). The State Earthquake Commission reported damage at localities near the fault zone due to the famous 1906 earthquake. The location of the fault across the neck of land was traced as a multitude of small cracks in the swampy land from the bay to the road and then as a well-defined fissure for 200 yards toward the north, disappearing beneath the sand dunes.

\section{JUSTIFICATION AND AUTHORIZATION}

From the mid-1800s to about 1876, the port of Bodega Harbor was used to transport produce and lumber to San Francisco and to house a small fleet of fishing vessels (Karp, 1975). Crop cultivation and cattle overgrazing in the area caused sheet erosion and contributed substantially to the silting up of the harbor. The advent in 1876 of the North Pacific Coast Railroad, running from Sausalito to Duncan's Mills, resulted in a further decline of the port. Sailing vessels could not compete with the cost and speed advantages of the railroad.

Due to increasing usage and efficiency of automobile and truck transport modes, the small railroad was forced out of business by the early 1930s. At that time, local interests undertook to dredge a small channel from the landings to the eastern shore of the lagoon toward the natural main channel. Interest in port activity had intensified due to the more prevalent use of motorized vessels. A report commissioned by the Congressional Committee of Rivers and Harbors during the 1930s described the inlet and approach to the landings as follows:

"The locality under consideration is a triangular inner bay about 8,000 feet wide and 9,000 feet long between the above peninsula and the general shore, and separated from Bodega Bay proper by a narrow sandspit. Entrance into the inner bay is by a channel, about 3 feet deep, between Bodega Head and the western end of the sandspit. Inside the entrance there is a curved channel, with a controlling depth of about 2 feet, to the northern apex of the inner bay, where there is a small area from 8 to 9 feet deep. Most of the remainder of the inner bay is exposed at low water."

As a result of the suggestions for improvement contained in the report, work was authorized and the jetties, bulkheading, and main channels and turning basins were completed by 1943. 


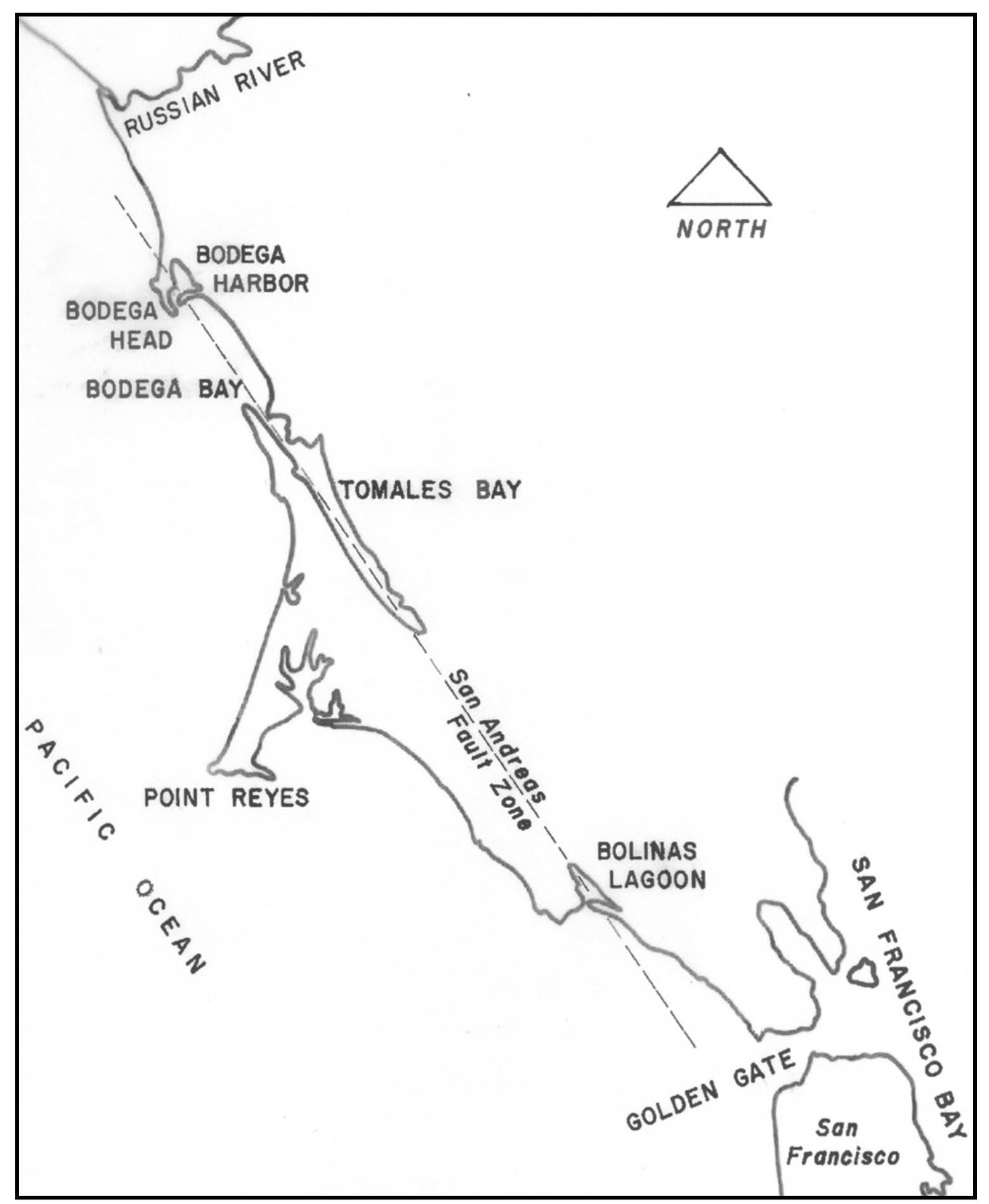

Figure 2. Location of Bodega Harbor, Sonoma County, California, USA 


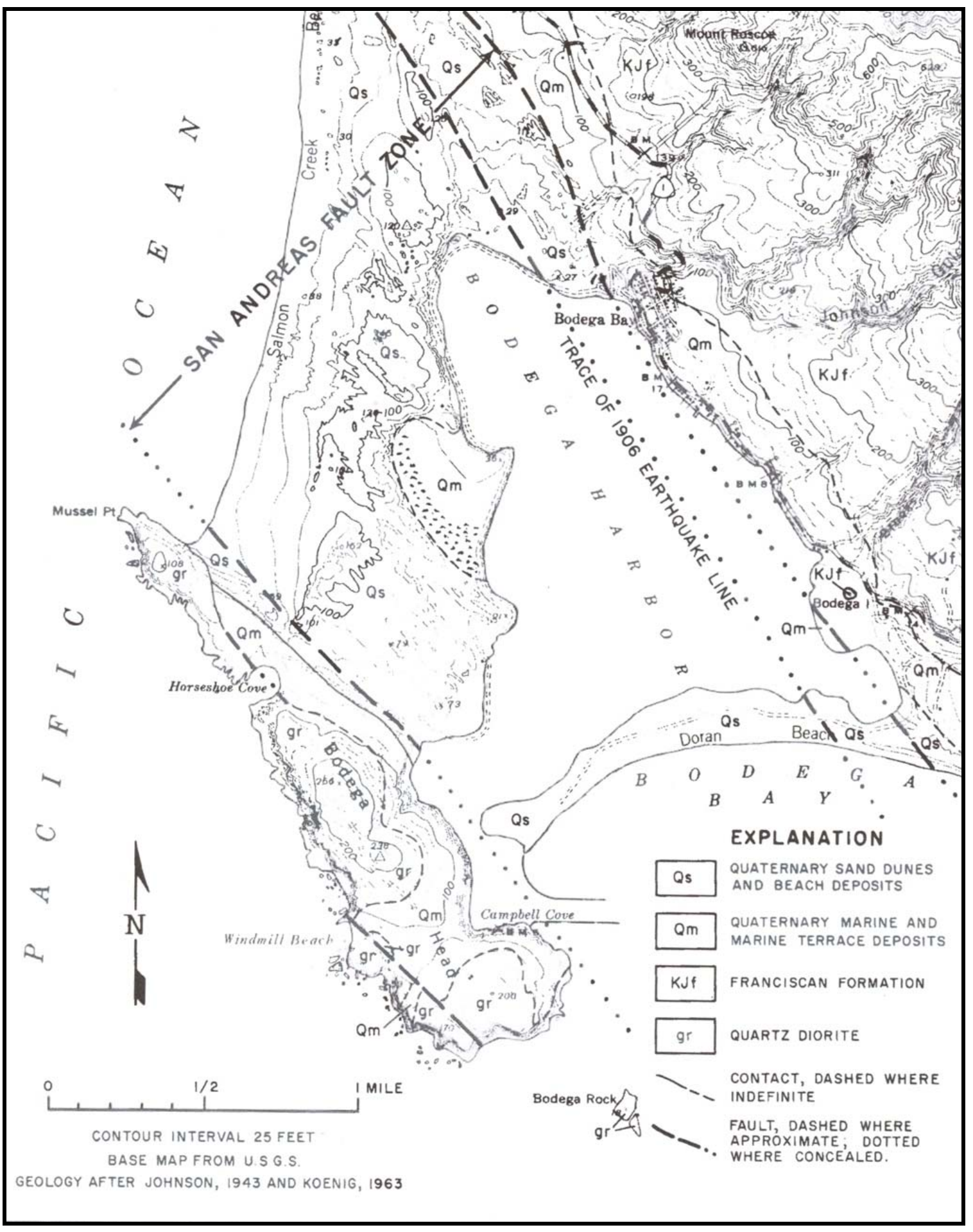

Figure 3. Geologic Map of Bodega Harbor, including the San Andreas Fault Zone 


\section{DESIGN AND CONSTRUCTION}

Bodega Harbor is separated from Bodega Bay and the Pacific Ocean by a typical hooked sandspit. As discussed by Johnson (1965), a hooked sandspit is a coastal feature produced by deepwater waves from a predominant direction. In this case, the predominant deepwater waves from the northwest (Figure 4) diffract and refract around Bodega Head.

Over geologic time, coastal sands have been driven to form the hooked sandspit now called Doran Beach. This area has become a popular recreation destination and the sand is well-graded and largely composed of quartz. The floor of Bodega Harbor is generally composed of fine-grained sediments such as silt, clay, and sand, and much of the floor is exposed at low tide.

During the 1930s timeframe in which the jetties were designed, it is highly probable that the pioneering work of O'Brien (1931) was used to calculate the spacing (about 100 feet) of the proposed entrance jetties. O'Brien states that “....along the Pacific coast the United States the tide exhibits a diurnal inequality with the long run-out following higher high water....this peculiarity in the daily sequence gives strong ebb currents in comparison with flood currents.”

The authorized federal project included two entrance channel jetties, an embedded timber bulkhead (3,100 feet in length) to retain the sandspit, and dredging of interior channels and turning basins. About 164,000 tons of local sandstone (graywacke) was used for construction of the two jetties.

As equipment access to the south jetty (which is adjacent to Bodega Head) is difficult and access to the north jetty via the sandspit allowed use of land-based equipment, the construction access for both jetties was established from the north. A temporary timber pile-supported roadway from the north jetty area to the south jetty area, with a central lift section to allow for vessel traffic, was constructed as shown in Figure 5. Also shown in Figure 5 is the cutter head dredge used in developing the associated navigation channels. Construction details and cross-sections of the two jetties are shown in Figure 6.

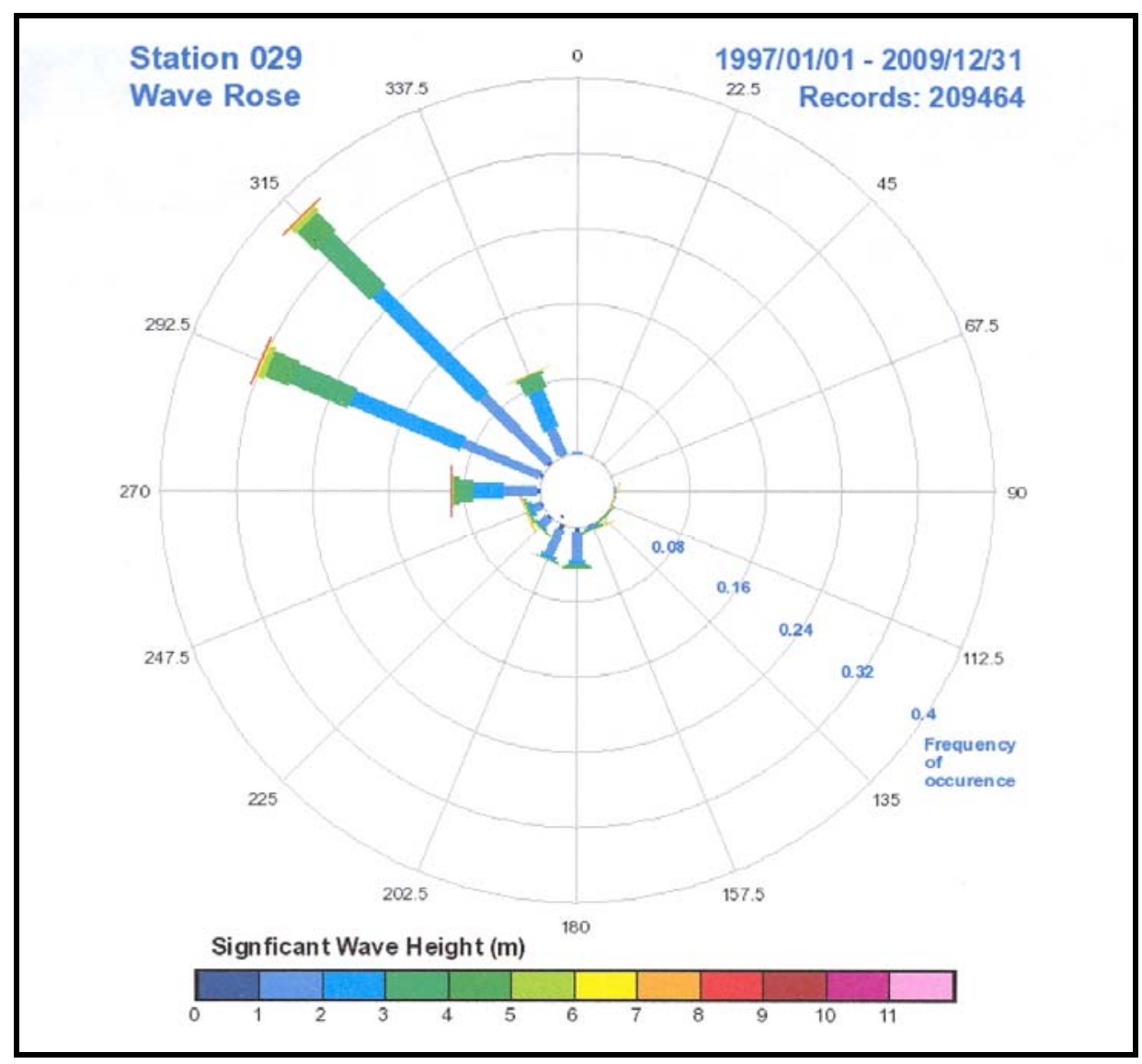

Figure 4. Wave Rose from Deepwater Buoy West of Point Reyes (courtesy of CDIP Program at Scripps) 
Figure 5. Construction of Bodega Harbor Jetties by Corps of Engineers, 1942 (Photograph provided by Joel Hack of the Bodega Bay Navigator)

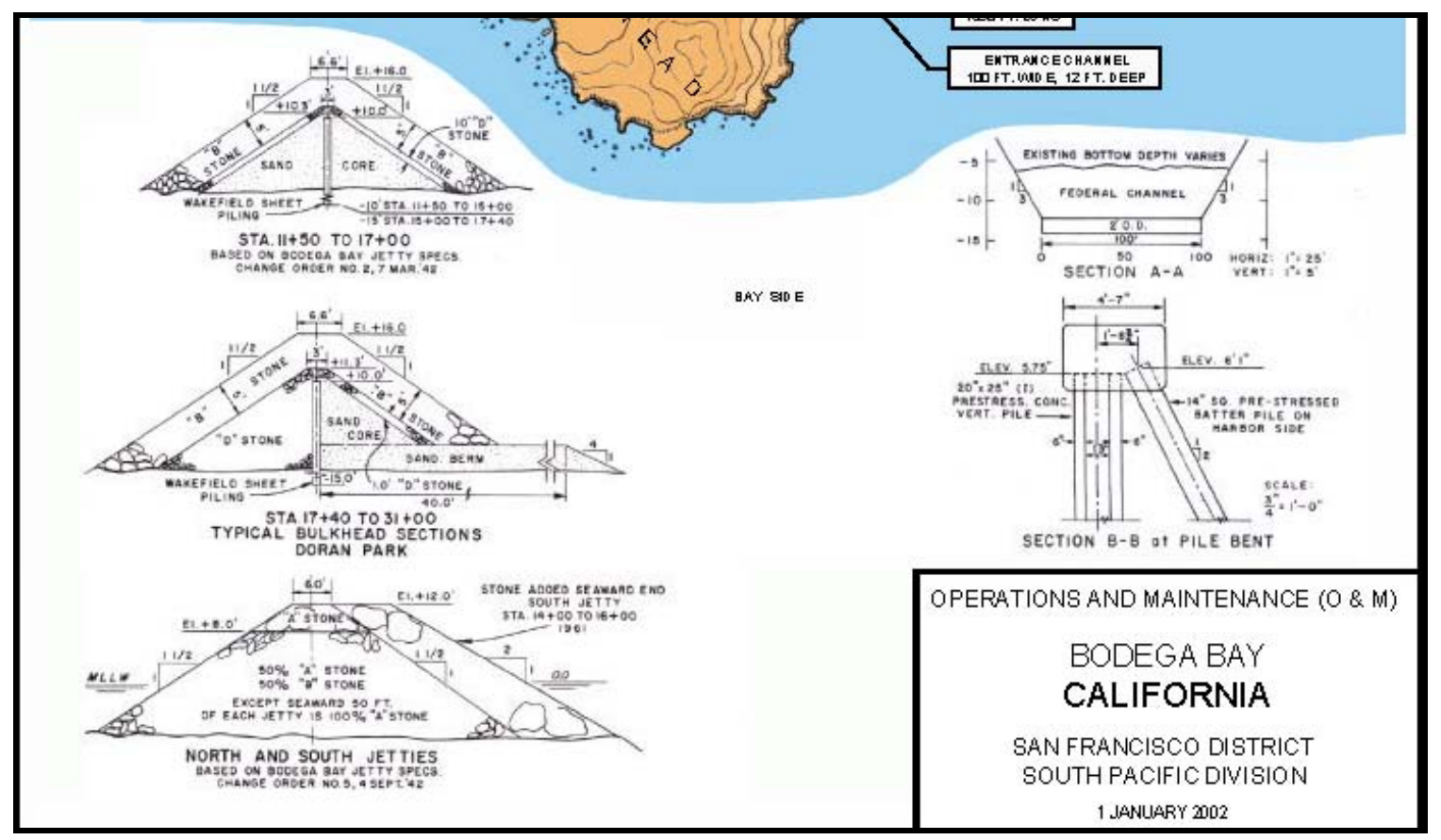

Figure 6. Construction Details and Cross-Sections of the Bodega Harbor Jetties 


\section{MONITORING AND IMPROVEMENTS}

By the early 1960s, settlement and/or loss of armor stone had occurred along the seaward portion of the south jetty (Corp of Engineers, 1963). This area was rebuilt in 1961 where the crest of the seaward end of the south jetty was widened and the slopes flattened to $1 \mathrm{~V}: 2 \mathrm{H}$. The amount of stone used to improve the south jetty was about 17,200 tons, slightly more than 10 percent of the tonnage used in the original construction. Improvements to the north jetty were not needed. The jetties were reviewed and observed in detail by Karp in 1975 (see Figure 7).

In the 1980s, an extensive review and inspection (Corps of Engineers, 1986) of both jetties was conducted under the direction of the senior author, who also participated in all of the field studies. The field studies included aerial photography, soundings, and side scan sonar. These efforts were supplemented by inspection dives along with extensive sampling and testing of the armor stone. The field studies were designed to:

- $\quad$ Determine bathymetry around the structures.

- Locate holes, slumps, or other major irregularities in underwater armor position and/or slope of the structures.

- $\quad$ Locate any geologic faults (the jetties are within the San Andreas Fault zone).

- Identify the top foundation underlying the structure.

- Locate armor loss voids.

- Locate erosion areas.

- Identify any capstone separation from the core materials.

- Identify any scouring problems.

- $\quad$ Determine if materials were deteriorating from stress.

The review and inspection indicated that although some stone was displaced or missing from both jetties, no repairs were warranted. It was recommended that the jetties continue to be monitored on a regular basis to ensure that any major structural problems or deficiencies were noted in a timely manner.

Given the well-documented maintenance problems and failures (Magoon, Sloan, and Foote, 1974; Whalin, 1994) that have plagued many coastal structures, it appears that the Bodega Harbor jetties have generally performed well over the decades. And, as relatively little shoaling has occurred in the improved entrance channel, the planning, design, construction, monitoring, and maintenance of both jetties is considered satisfactory and they are serving the purpose for which they were designed. This opinion was confirmed by visual observations made by the senior author in June 2010 (Figure 8).

\section{SUMMARY AND CONCLUSION}

To create and maintain a navigable entrance for small craft between the Pacific Ocean and Bodega Harbor, the construction of two rubble-mound jetties and associated dredging of interior channels were authorized by the United States Congress in the late 1930s. In 1942, the two rubble-mound jetties were constructed at the historic natural harbor (lagoon) entrance.

By the late 1950s and the early 1960s, some settlement and/or loss of armor stone had occurred along the seaward portion of the south jetty, in the area most exposed to ocean waves. This area was rebuilt in 1961 where the crest of the seaward end was widened and the slopes were flattened. The north jetty did not need repair or improvement.

In the early 1980s, a detailed evaluation of both jetties showed that although a few stones were displaced or missing from both jetties, repairs to the jetties were not warranted. It was recommended that the jetties continue to be monitored on a regular basis to ensure that any major structural problems or deficiencies would be noted in a timely manner.

The planning, design, construction, monitoring, and maintenance of both jetties at Bodega Harbor are considered satisfactory and the jetties are successfully serving their intended purposes.

\section{ACKNOWLEDGEMENTS}

Assistance provided by the Corps of Engineers (San Francisco District, South Pacific Division), the Water Resources Center Archives (University of California, Berkeley), and Joel Hack of the Bodega Bay Navigator and West Marin Citizen newspapers is gratefully acknowledged. The authors also appreciate the support, encouragement, and enthusiasm of their families, friends, and colleagues 


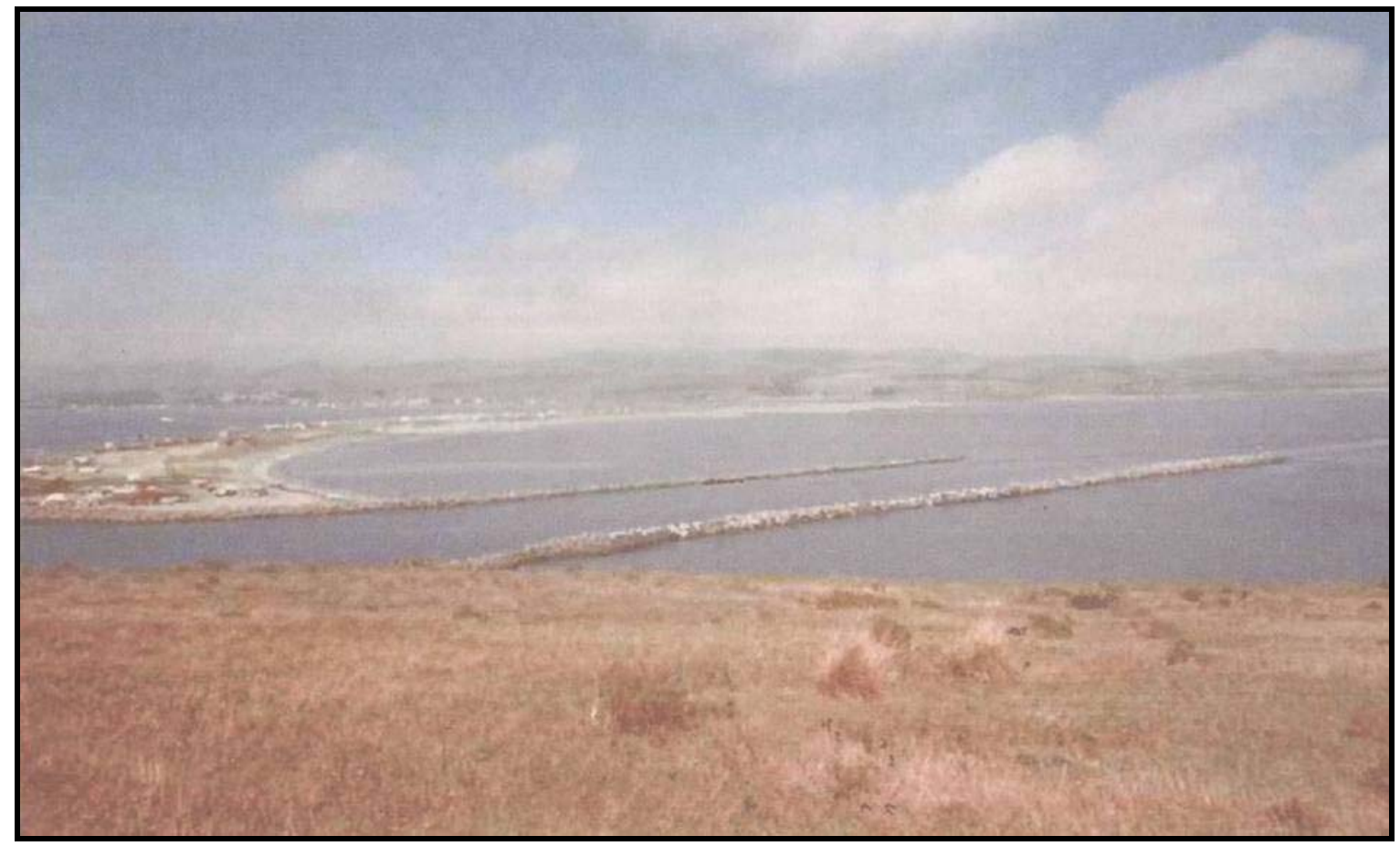

Figure 7. Bodega Harbor Jetties and Doran Beach Looking to the Northeast (1975) (Photograph by Lawrence B. Karp)

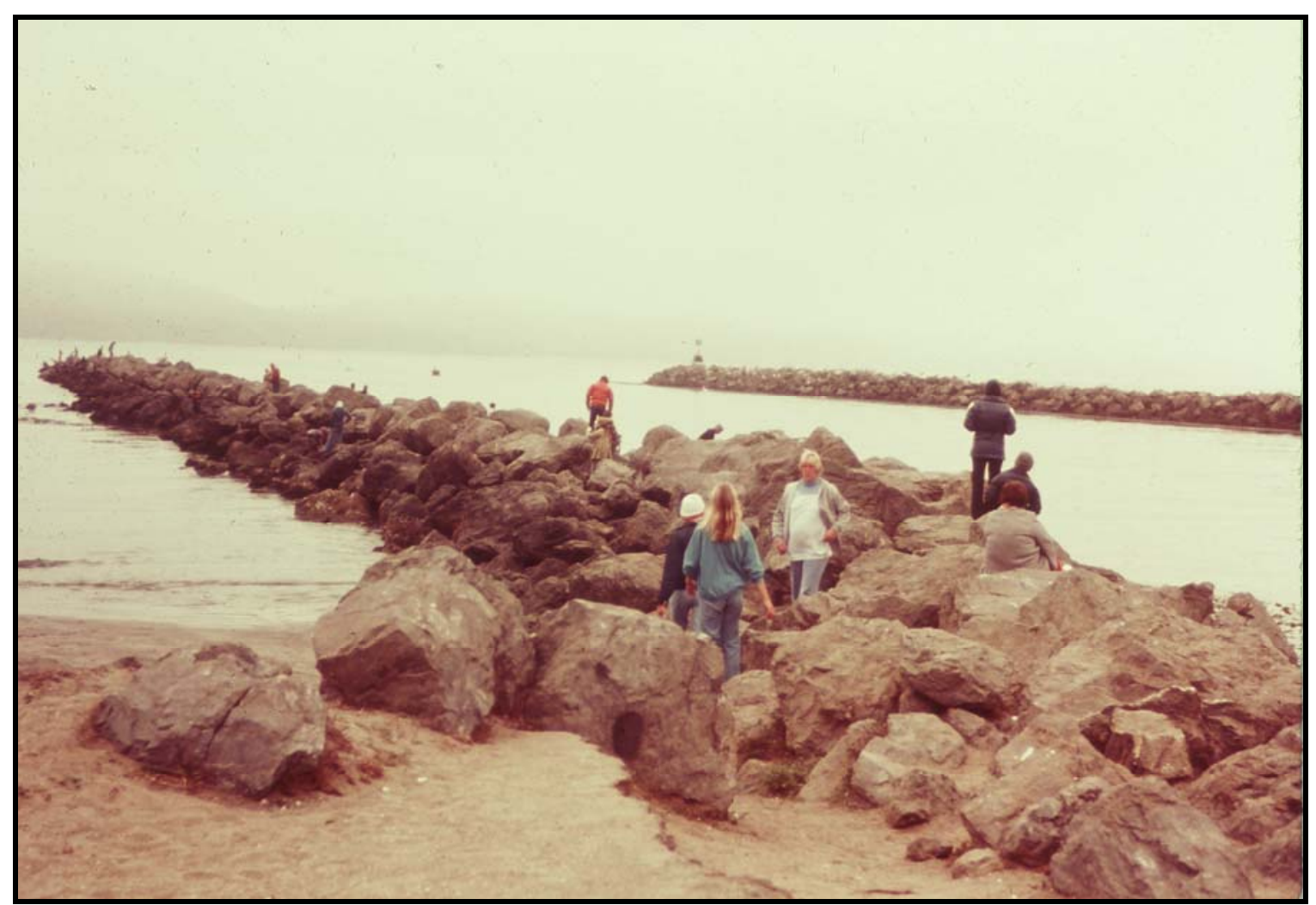

Figure 8. Bodega Harbor Jetties in June 2010

(Photograph by Orville T. Magoon) 


\section{REFERENCES}

Corps of Engineers (1963), Review of Reports - Bodega Bay, California, United States Army Corps of Engineers, San Francisco District, San Francisco, California.

Corps of Engineers (1986), Comprehensive Condition Survey - North and South Jetties - Bodega Bay, Sonoma County, California, United States Army Corps of Engineers, Los Angeles District, Los Angeles, California.

Iacopi, R. (1964), Earthquake Country, Lane Book Company, Menlo Park, California, 192 pages.

Johnson, J. W. (1965), Nearshore Sediment Movement - Central California Coast, Proceedings, Coastal Engineering Specialty Conference, Waterways and Harbors Division, ASCE, Santa Barbara, California, pages 537-559.

Johnson, J. W. (1973), Characteristics and Behavior of Pacific Coast Tidal Inlets, Journal of the Waterways, Harbors and Coastal Engineering Division, ASCE, August 1973, pages 325-339.

Karp, L. B. (1975), Review of Coastal Changes at Bodega Harbor Inlet, Independent Study (CE 299) Report, Department of Civil Engineering (Prof. J. W. Johnson), University of California, Berkeley, 52 pages.

Koenig, J. B. (1963), The Geologic Setting of Bodega Head, Mineral Information Service, Division of Mines and Geology, State of California, July 1963, 10 pages.

Magoon, O. T., Sloan, R. L., and G. L. Foote (1974), Damages to Coastal Structures, Proceedings, $14^{\text {th }}$ International Conference on Coastal Engineering, ASCE, Copenhagen, Denmark, pages 16551676.

O’Brien, M. P. (1931), “Estuary Tidal Prisms Related to Entrance Areas”, Civil Engineering, ASCE, May 1931, pages 738-739.

Schulz, S. S. and R. E. Wallace (1997), The San Andreas Fault, United States Geological Survey, General Interest Publication, Menlo Park, California, 16 pages.

Treadwell, D. D., Rietman, J. D., Weaver, K. D., and G. J. Murphy, (1980), Offshore Faulting in the Gulf of the Farallones, Proceedings, 12th Offshore Technology Conference, Houston, Texas, Paper OTC 3916, pages 611-616.

Treadwell, D. D., Noble, R. M., and O. T. Magoon (2005), Tidal Inlet and Lagoon on the San Andreas Fault, Proceedings, ICS 2005, International Coastal Symposium in Iceland, Hofn, the Town of Hornafjordur, Iceland, June 2005

USGS (2001), Beyond the Golden Gate: Oceanography, Geology, Biology, and Environmental Issues in the Gulf of the Farallones, United States Geological Survey, Circular 1198, Reston, Virginia, 78 pages.

Whalin, R.W. (1994), An Overview of Rubble-Mound Breakwater Development in the United States, Proceedings, Case Histories of the Design, Construction, and Maintenance of Rubble Mound Structures, ASCE and the Coastal Zone Foundation, Eureka, California, pages 1-15. 